Library, of the deep personal interest taken by him in the progress of the College as a place of higher education and learning." (2) "That the Court accepts with great pleasure the munificent offers of two friends of the College of the sums of $10,000 l$. for the erection, and of $5000 \mathrm{l}$. towards the maintenance, of suitable buildings for the physical laboratory, and requests the Principal to convey to them its sincere thanks for their wise and opportune generosity, which will enable the College to advance and develop a scientific teaching and research of the highest public importance and utility." (3) "That the Court accepts with great pleasure the generous and useful gift of Mr. Edward Holt to the College, and desires the Treasurer to express their best thanks to him. The Court also hopes that the Council will take steps to associate the name of Mr. Holt in some permanent manner with the new gymnasium."

SEVERAL of the London polytechnics have commenced the present session with some new developments in their day work. The Battersea Polytechnic is inaugurating day courses in technological chemistry, specially adapted to persons engaged in those industries for which a knowledge of chemistry is useful. The South-west London Polytechnic is not only developing its day engineering courses, but is also providing special facilities for students who wish to enter for the examinations of London University, and is starting a day department for women, in which opportunities will be given to pursue advanced studies in art, science, and languages. The East London Technical College, People's Palace, is further developing the day courses which were commenced last year. Courses in physics and electrical engineering are now given, as well as in chemistry and mechanical engineering, while facilities are offered to students to study for the various subjects of the London B.Sc. examinations. The Borough Polytechnic, besides adding considerably to its provision of scientific and technical instruction for artisans, has opened a technical day school for boys, which is specially designed to fit its pupils for entering on industrial life.

\section{SCIENTIFIC SERIALS,}

American Journal of Science, September. - Principal characters of the Protoceratidæ, by O. C. Marsh. The genus Protoceras, described by the author in $189 \mathrm{I}$, from the Miocene of South Dakota, is now known to include some of the most interesting extinct mammals yet discovered. It likewise represents a distinct family, and thus deserves careful investigation and description. Before this discovery, no horned artiodactyles were known to have lived during Miocene time, and Protoceras is thus the earliest one described. The type specimen, moreover, had a pair of horn-cores on the parietals, and not on the frontals, as in modern forms of this group. The animal was apparently a true ruminant, nearly as large as a sheep, but of more delicate proportions. Another notable feature is the very large, open nasal cavity. This peculiar feature is of even greater importance than the horn-cores, and indicates clearly in the living animal a long flexible nose, if not a true proboscis. The paper is illustrated by a series of admirable plates. - The theory of singing flames, by $\mathrm{H}$. V. Gill. If a singing flame is produced by inserting a burning gas jet into a tube, the pressure during a condensation forces the burning gas back into the nozzle of the jet. This can be made evident by observing the image of the flame in a rotating mirror, when a small flame is seen below the level of the nozzle, corresponding to the gaps in the main flame. -Oscillatory discharge of a large accumulator, by J. Trowbridge. The discharge from a large number of Planté cells is characterised by a sibilant flame which, by quickly separating the spark terminals, can be drawn out to a length of several feet. It closely resembles the light produced by passing an electric spark through lypocodium powder. When a photograph of this flaming discharge is examined, it is seen to have an intensely bright spark as a nucleus. By using an arrangement to blow out the flame, it was found possible to examine the spark by means of a revolving mirror. The photographs then showed five or six distinct oscillations. The author concludes that a cell may be regarded as a leaky condenser, and that its discharge is always essentially oscillatory. - Electric discharges in air, by the same author. The voltaic arc is a kind of flaming discharge as above described. Its resistance may be studied by the damping method. The author fed an arc light by a continuous current and by a condenser discharge, and found the resistance to be $0.8 \mathrm{ohms}$, which was independent of the length of the arc.-On Pithecanthropus erectus, by L. Manouvrier. The degree of fossilisation of the Trinil remains is such that the femur attains the weight of I kilogram, whereas prehistoric femurs of the same size do not exceed $35^{\circ}$ grams. The important fact established by Dubois is that the craniological inferiority of human races increases with their antiquity. The known anthropoid genus to which the intermediate Pithecanthropus is most closely allied is the Gibbon (Hylobates). If the Pithecanthropus was a simple precursor of man, it was superior enough to the other animals to survive unless the human species hastened to annihilate this dangerous competitor. If it was an ancestor, its species lives yet in its human descendants.

Wiedemann's Annalen der Physik und Chemie, No. 9.-Action at a distance, by P. Drude. Action at a distance may be defined as a relation between two bodies such that the energy of the system depends not only upon their velocities, but also upon their mutual position. Contact action may take place by impact or through the intermediary of an elastic solid or a fluid, compressible or incompressible. Gravitation has not yet been reduced to a contact action, owing chiefly to the fact that its velocity of propagation through space has not yet been ascertained. According to Laplace, this velocity must be at least ten million times that of light. - Grey and red incandescence, by O. Lummer. Draper's assertion that all bodies begin to glow at the same temperature has been disproved by H. F. Weber and Emden, who showed that the first indication of a grey misty light occurs at temperatures ranging from $403^{\circ}$ (German silver) to $423^{\circ}$ (gold). The grey glow appears to fluctuate and flit about, but the image becomes fixed as soon as the red glow sets in. This may be explained by the constitution of the eye. The rods perceive the grey glow. The fovea centralis contains no rods, and hence the light is not seen if looked at direct. The cones, on the other hand, are the instruments of colour perception. They alone line the fovea centralis, and hence the red light is seen in its proper place. At a sufficiently feeble intensity the solar spectrum appears colourless along its entire length.-Glow on insulated conductors in a high-frequency field, by $\mathrm{H}$. Ebert and E. Wiedemann. The authors place a wire or rod in a bulb or cylinder placed between the terminal condenser plates of a Lecher wire system, so that it hangs parallel to the axis of the condenser. A slight exhaustion suffices to produce a blue glow against both ends of the rod on the glass surface, which spreads out in all directions, and shows forms resembling Lichtenberg's figures. As exhaustion proceeds, the glow extends over the surface of the rod, and forms a bridge across the middle. The occurrence of this bridge is retarded by making the rod thicker, or using several wires, or substituting a tube for the rod.-Discharge inside a wire gauze box, by the same authors. If a cylindrical box of wire gauze is placed inside an exhausted tube, the glow of the gas is observed to penetrate inside the gauze, especially if the box is short.-Method of making lines on glass visible as light on a dark ground, by F. F. Martens. If a glass plate is illuminated through its end surfaces, no light penetrates through the large surfaces owing to total reflection. But if lines are etched into them or cut with a diamond, they appear bright on a dark ground.-Electric viscosity of insulators, by G. Quincke. The logarithmic decrement of a glass sphere suspended from the arm of a balance in ether is increased from 0.0210 to 0.0608 in a field produced by 2000 volts. The difference may be termed the electric viscosity.

\section{SOCIETIES AND ACADEMIES. PARIS.}

Academy of Sciences, October 4.-M. A. Chatin in the chair.-On ancient glass mirrors backed with metal, by $M$. Berthelot. A description of some mirrors, of Gallo-Roman origin, dating from the third or fourth century. The metallic backing consists of lead, which would appear to have been applied in a molten state to the glass.-On the number and symmetry of the fibrovascular bundles of the petiole, in the measurement and classification of plants, by M. A. Chatin.Observations on the sun, made at the Observatory of Lyons with the Brunner equatorial during the second quarter of 1897 , by M. J. Guillaume. The results are summarised in three tables, showing the sunspots, their distribution in latitude, and the distribution of the faculæe in latitude.-Orthogonal systems for the derivatives of the $\theta$-functions of two arguments, by M. E. 
Jahnke.-On the differential linear congruences, by M. Alf. Guldberg.-A new method of testing metals, by M. Ch. Frémont. The size of the test pieces employed is much reduced $(20 \mathrm{~mm} . \times$ IO $\mathrm{mm} . \times 8 \mathrm{~mm}$.), and the resulting deformations enlarged ten times by photography. Methods are given for measuring the tenacity, ductibility, fragility, and homogeneity of the sample with sufficient accuracy for practical purposes. - Study of the normal variation of the earth's electric field with height, in the upper regions of the atmosphere, by M. G. Le Cadet. The results obtained show that the intensity of the electric field of the atmosphere diminishes when the height above the surface of the earth is increased. - On the fogging of the negative in radiography, by $M$. V. Chabaud.-On the solubility of liquids, by MM. A. Aignan and E. Dugas. A criticism of the work of Alexejew on the same subject.-Action of gravity on the growth of the lower fungi, by M. Julien Ray. The action of gravity is to retard the growth. The experiments were carried out upon cultures of Sterigmatocystis alba, some of which were at rest, and others moving uniformly in a vertical plane.

\section{New South Wales.}

Linnean Society, August 25.-Prof. J. T. Wilson, President, in the chair.-Descriptions of Australian Micro-Lepidoptera; Part xvii., Elachistida, by E. Meyrick. The number of species recorded in this paper was $\mathbf{2 5 4}$, referable to thirty-seven genera. Nearly the whole of the species are new to science. - Note on the occurrence of sponge remains in the Lower Silurian of New South Wales, by W. S. Dun. Until last year fossiliferous rocks of Ordovician age were not known to occur within the geographical boundaries of New South Wales. A species of Protospongia, associated with graptolites in a bluish slate, is recorded from Stockyard Creek, County of Wellesley, N.S.W. The specimens, which are pyritised and show no great amount of detail, were collected by Mr. J. E. Carne, of the Department of Mines. The Wellesley beds are probably of the same age as those of the Castlemaine and Bendigo districts of Victoria, certain fossils from which have been reported upon by Mr. T. S. Hall.-Descriptions of two new species of Pultenca, by $R$. T. Baker. Mr. Baker exhibited, on behalf of Mr. C. E. Finckh, of the Technological Museum, a specimen of a comparatively rare fish, Moncentris japonicus, Houtt., caught by a fisherman at Newcastle. In regard to this fish, Mr. Ogilby pointed out the presence of luminous discs, which he believed were of use as traps; he also remarked that no articulation of the scales so as to form "a coat of mail" existed in Australian specimens, such as is attributed to Monocentris japonicus. The presence of two separate dorsal fins removes this genus from the Berycida, and its nearest ally is the rare deep-sea Anomalops, with which it agrees also in the presence of liminous glands and of membranous interspaces between the bones of the cranium.- Mr. Brazier sent for exhibition six specimens of Helix vermiculata, Müller, obtained alive by him on July ${ }_{13}, 1897$, on the buffalograss in the Waverley Cemetery. This is the first Australian record of this introduced European species, whose home is France, Spain, Italy, \&c. - Mr. Hedley exhibited, by permission of the Curator of the Australian Museum, a specimen of Cancellaria granosa, Sowerby, taken from the stomach of a schnapper hooked nine miles east of Wollongong, N.S.W., in 30-40 fathoms. An interest attached to this specimen is that though the species is well known in Tasmania, Victoria, and South Australia, it has not apparently been recorded previously from the coast of N.S.W. Mr. Hedley remarked that an exploration of the deep, cold-water current that lay off the coast would result in adding many other southern forms to our known fauna. A previous instance of such is the record [P.L.S.N.S.W. (2) iv. p. 749] of Crassatella kingicola, Lamk., a characteristically Tasmanian species trawled in 17 fathoms off Merimbula, N.S.W If fishermen could be induced to search the stomachs of fishes, a mass of valuable data would soon accumulate.-Mr. Norman Hardy read a note on, and exhibited specimens of, feathered arrows from the island of Espiritu Santo, New Hebrides. It has long been held as an ethnological axiom that no arrow from any Pacific island was feathered. This rule is now shown to have its exception, and for the first time the locality whence these feathered arrows come is now published.

\section{GötTingen.}

Royal Society of Sciences.-The Nachrichten (mathematico-physical section) part 2, 1897, contains the following memoirs communicated to the Society :-

NO. I 459, VOL. 56]
May I5.-George Landsberg: The algebra of the RiemannRoch theorem. O. Mügge : Translations and other related phenomena in crystals. J. R. Schiitz: The principle of the absolute conservation of energy.

May 29. - J. Orth : Researches carried out in the Pathological Institute at Cröttingen.

June 19. - A. Hurwitz: Linear forms with integral variables. L. Kriiger : A theorem in the combination of observations.

July 3.-E. Ehlers: East African Polychæte worms. C. Fromme: On magnetic hysteresis. P. Gordan: Hermite's reciprocity-theorem.

July 17.-W. Voigt : Determination of relative thermal conductivity by the isothermal method.

July 3r.-F. Klein: A new mannscript relating to Bernhard Riemann. A. Wiman : Note on the symmetrical and alternating interchange-groups of $n$ things. H. Minkowski : General theorems on convex polyhedra.

\section{BOOKS RECEIVED.}

Books.-Memory and its Cultivation: Dr. F. W. Edridge-Green (K. Paul). - Elements of Human Physiology: Dr. E. H. Starling, 3rd edition (Churchill).-Electricity in the Service of Man : Dr. R. Wormell, revised and enlarged by Dr. A. M. Walmsley (Cassell). - Botanical Observations on the Azores: W. Trelease.-Royal Gardens, Kew, Bulletin of Miscellaneous Information, 1896 (Eyre) - A Question of the Water and of the Land: Dante Alighieri, translated by C. H. Bromby (Nutt).-The Dwelling House : Dr. G. V. Poore (Longmans).--Lumen : C. Flammarion, translated (Heinemann). - I5 Lezioni Sperimentali su la Luce : A. Garbasso (Milano) -Year-Book of the U.S. Department of Agriculture, 1806 (Washington). The Principles of Chemistry, 2 Vols.: D. Mendeléeff, translated by G. Kamensky, edited by T. A. Lawson (Longmans).- The Machinery of the Universe : Prof. A. E. Dolbear (S.P.C. K.). - Sleep: its Physiology, Path-
ology, Hygiene, and Psychology (Scott).-A Memoir of Wm. Pengelly, ology, Hygiene, and Psychology (Scott). - A Memoir of Wm. Pengelly, F.R.S. : edited by his daughter, Hester Pengelly (Murray). - Missour
Botanical Garden, 8th Annual Report (St. Louis, Mo.), - Euvres Completes Botanical Garden, 8th Annual Report (St. Louis, Mo.), - Cuvres Complètes
de Christian 'Huygens, tome septieme ,(La Haye, Nijhoff).-Elementary de Christian 'Huygens, tome septieme '(La Haye, Nijhoff), - Elementary
Manual of Magnetism and Electricity : Prof. A. Jamieson, 4th edition Manual of Magnetism and Electricity : Prof. A. Jamieson, 4th edition
(Griffin). -The Principles of Alternate-Current Working: A. Hay (Biggs)

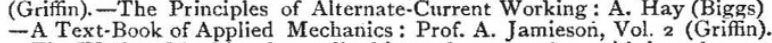
-A Text-Book of Applied Mechanics : Prof. A. Jamieson, Vol. 2 (Griffin).
-The Works of Archimedes : edited in modern notation, with introductory -The Works of Archimedes : edited in modern notation, with introductory
chapters, by Dr. T. L. Heath (Cambridge University Press). - Theory of Groups of Finite Order: Prof. W. Burnside (Cambridge University Press) The Röntgen Rays in Medical Work: Dr. D. Walsh (Baillière). -Darwin and after Darwin: Dr. G. J. Romanes, III. (Longmans).- John Hunter S. Paget (Unwin). - Les Fonds Electriques et leurs Applications: A. Minet (Paris. Gauthier-Villars).-Die Meteoriten in Sammlungen und ihre Literatur: Dr. E. A. Wülfing (Tübingen, Laupp).-Luce e Raggi Röntgen : Prof. R. Ferrini (Milano, Hoepli).

\section{CONTENTS.}

PAGE

Hindu Castes and Sects. By Dr. M. Winternitz . 56r Experimental Morphology . . . . . . . . 563 Our Book Shelf:-

Conn: "The Story of Germ Life. Bacteria."-Mrs. Percy Frankland

Redway: "Natural Elementary Geography" . . . 565

"Kew Bulletin of Miscellaneous Information, 18.86 " 565

Ingersoll : "Wild Neighbours."-L. C. M. . . . . 565

Letters to the Editor:-

Edible Copepoda.-Prof. W. A. Herdman, F.R.S.

Brief Method of Dividing a Given Number by 9 or I I. - Rev. Charles L. Dodgson . . . .

Notes on Madagascar Insects. - E. L. J. Ridsdale . 566

Protective Colouring.-Alfred O. Walker . . . . 566 The Mechanism of the First Sound of the Heart . 567 The Divining Rod . . . . . . . . . . 568

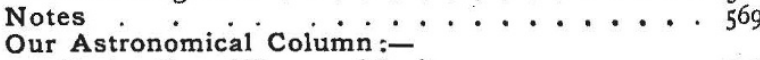

Conjunction of Venus and Jupiter . . . . . . . 573

The Level of Sunspots . . . . . . . . . . 573

The Orbit of Comet I822 IV. . . . . . . . . 573

The late Alvan G. Clark . - . - $\cdot$ the British 574

A Plea for a Bureau of Ethnology for the British Empire. By Prof. A. C. Haddon . . . 574

Insects and Yeasts. (Illustrated.) By Prof. Italo

Giglioli ' W i f the Royal Gardens, Kew . * 575

Ten Years' Work of the Royal Gardens, Kew . . 577 The Duke of Devonshire on Scientific Education . . . 580 Scientific Serials .......... . . 583

Societies and Academies . . . . . . . . . . . 583

Books Received ........... . . 584 